\title{
THE POLITICIAN/CELEBRITY AND FAN(GIRL) PLEASURE: THE LINE BETWEEN QUEEN HILLARY AND PRESIDENTIAL CANDIDATE CLINTON
}

\author{
JOCELYN SMITH
}

\section{ABSTRACT}

Whenever there is a major political event and the \#TheBachelor livetweeting continues, or popular online media outlets such as Jezebel go ahead with their pre-planned celebrity gossip coverage, there is outrage: seemingly, it is impossible to keep up with-and care about-both the Kardashians and election campaigns. During the 2016 United States' election, however, this outrage emerged from within campaign coverage, drawing a line between "serious political supporter" (who is interested in facts and policy) and "emotional fangirl" (who is interested in memes, feelings, and "girl power" above all).

Despite Donald Trump's history of reality TV and non-political celebrity, Hillary Clinton's supporters were called "fangirls" and accused of celebrity-worship, of solely getting their news from "pop" media like BuzzFeed-where foreign policy coverage is found alongside discussions of how "dead" we are from a Clinton eyeroll-and of allowing fandom to cloud political judgment. This paper is not engaging in the "fake news" debate; rather, this paper explores the intersection of political celebrity and politician in a moment when governmental politics, celebrity, social media, and reality TV are overlapping in unprecedented ways, as well as the intersection of "serious" political campaigning and fannish pleasure in an historic moment for women in American politics.

\section{KEY WORDS}

Political Persona; Social Media; Fandom; American Politics; Hillary Clinton; Postfeminism

\section{TRUMP’s TWITTER, HILLARY's FANGIRLs: RESPONDING TO “THIS POLITICAL Climate"}

It seems urgently necessary and, at the same time, redundant to talk about the celebrity persona of the politician, or the politician as a celebrity persona, in a post-2016 North America. The explosive and polarising events of the 2016 U.S. election left many people, myself included, hesitant about how to continue talking about political persona, and the celebrity practices employed by politicians, particularly through social media such as Twitter. Perhaps this is indicative of late night comedians becoming America's hardest-hitting reporters, but the mere mention of a politician tweeting sounds more like a punch line, or the beginning of a rallying speech, than an academic essay. The papers I received from my first- and second-year students 
in the Winter 2017 term, following Donald Trump's election and Hillary Rodhami Clinton's historic loss, showed this same kind of hesitancy; they kept vaguely referring to "this political climate", as a catch-all phrase for "stuff got weird and I don't know how to write about it in the 'unbiased' way I've been trained to write in high school".

But "this political climate" and the "weirdness" of the past two years is not only referring to Trump's election, his celebrity status and dynastic-business-tycoon-cum-reality-star persona, or his cultivation of his reactionary political persona through his unconventional use of Twitter. It also refers to Clinton's historic campaign, how her political persona, and her use of celebrity practices and strategies, created an unprecedented narrative of "fangirling" around the election. That is, young women in particular were understood to be fans of Clinton's rather than constituents or supporters, and this language of emotional attachment, as opposed to critical distance, was used to dismiss Clinton and her voter base along gendered lines. Clinton's political persona became deeply intertwined with her social positioning within feminised spaces of pop culture and the rallying, emotional cries of "girl power". It is not enough to say that "what happened", and why Clinton lost, is "simply" because she is a woman. Her inability to seize the presidency, and to seize presidentiality, is rooted in "a new, unstable political environment" that requires "the massive mediatisation of the self through the integration of online culture into everyday life" (Marshall \& Henderson 2016, p. 1), and that brings the previously private expressions of feminised emotional attachment and "fangirling" into the public sphere.

This paper is a preliminary exploration into the role of "fangirling" in Clinton's historic loss. The discussion to come continues the work on political persona done in the wake of Brexit and Trump through a consideration of the intersecting discourses of pop culture fandom and postfeminism. The concept of "persona", and political persona in the age of social media in particular, provides the groundwork to begin to take up these questions as persona studies as a field, first, recognises the political dimension of all social interaction and, second, bases its understanding of the individual as a relation to the social-"[persona] is neither individual nor collective, but rather the way the individual negotiates their move into the collective and the way that collective interprets this now organised individual entity" (Marshall \& Henderson 2016, p. 3). I would add that, especially in Clinton's case, the way the collective reflects and is incorporated into this now organised individual entity is crucial to political persona as well.

In P. David Marshall and Neil Henderson's introduction to the topic of political persona (2016, p. 1), they claim: "persona is a way to explore and investigate this shift [in the media environment] and moment of instability, both in the way it operated in the past as a mediatised identity, and the way it is now pandemic and pervasive as a way of being in contemporary culture". Through an analysis of the evolution of Clinton's political persona, her postfeminist "girl power!" messaging, her public relationships with other female politicians, celebrities, and her "regular" supporters, and the particular gendered rhetoric of emotional attachment surrounding her 2016 campaign, this paper continues the work on political persona introduced by Marshall and Henderson last year when they asked: "what makes political persona constitutively different today than in the past" (p. 1)? On the flip side, how is the past present in today's political persona?

A politician having "fans" is not a new phenomenon-the Kennedys certainly had fans, and Hollywood celebrity affiliations; Ronald Reagan certainly did as well, albeit in a different way; Alexander Hamilton has cultivated a celebrity persona and fan base posthumously through a Broadway musical; and, thinking more globally, Winston Churchill had and has fans, and gains more as he continues to be represented in film and television (e.g. Netflix's The Crown; BBC's Peaky Blinders, both within the last few years), as does the frequently shirtless Vladimir Putin, 
whose images make the rounds on social media. A fan, particularly a fan of a politician, is understood differently than a supporter. This is similar to the often fraught distinction between fan and academic, where the fan is understood, as delineated by Joli Jenson in The adoring audience (1992, pp. 9 \& 19), as "deviant" and "excessive" for their passion and investment in an "object of desire [...] popular with the lower or middle class [...] and widely available", as opposed to the academic, whose interests fall in line "with the wealthy and well educated" and thus are understood to be "preference, interest or expertise" rather than unfiltered enthusiasm.

Politicians are not the kinds of cultural texts and objects of desire/interest Jenson describes. And while certain politicians, and their supporters, may be taken more or less seriously based on their class positions (this was certainly the case for George W. Bush and Donald Trump and their supporters, and how they were represented particularly in leftist conversation), it is not specifically class I want to consider here. I focus on age and gender, and how "the girl" as subject position connotes a passion and lack of detachment that precludes critical distance and becomes grounds for the dismissal both of the girl and the object of her passion and attachment. For Clinton's supporters (her voters, both famous and not, as well as her political campaigners and colleagues), to be cast by both sides as not only fans, but fangirls, contributes to the construction of a political persona that is, first, closely tied to the frivolity and femininity of Hollywood and "traditional" pop culture celebrity (as opposed to political celebrity), and, second, connotes an immaturity and an inability to make decisions based on reason and logic, as opposed to instinct and emotion.

Whenever there is a major political or world event and the \#TheBachelor live-tweeting continues, or popular (women's) online media outlets such as Jezebel go ahead with their preplanned celebrity gossip coverage, there is outrage. It is seemingly impossible to keep up withand care about - both the Kardashians and election campaigns, particularly for girls and women. Similar to the way the female sports fan needs to prove her fandom through knowledge of obscure trivia, it seems that girls and women must prove their commitment to serious news and topics - or sports-by abstaining from their more frivolous passions during more serious times. It is this distinction between the serious and the frivolous, and how this distinction occurs along gendered lines, that is at the core of my analysis of Clinton's political persona. Political persona is distinct from, although inextricably related to, "persona" more broadly, as it is based not necessarily on a desire for emotional attachment or affective response (although this is part of it), but on her "claim to explicit, legitimate political authority over others, and the means by which these claims are accepted" (Marshall \& Henderson 2016, p. 16). Thus, while I explore Clinton's persona in relation to pop culture fandom and the rhetoric of "fangirling" more broadly, my goal is to bring these increasingly more public discussions of fan attachments specifically into the conversations around (gendered) political persona that have come to the fore in the field of persona studies.

Rhiannon Bury, in Cyberspaces of their own: female fandoms online (2005), argues that this view of female fans, and girls and women generally, as unable to separate their fannish passions from more serious concerns has as long a history as the concept of "fandom" itself. Bury states:

In the 1920s, when the abbreviation of the Latin fanaticus came into use, sports writers used it playfully whereas film and theater critics used it pejoratively in reference to women who supposedly attended performances for the sole purpose of admiring the actors. (pp. 36-37)

To be a fan of sports, an area of pop culture fandom dominated by boys and men, is to be playfully engaged-and to be playfully engaged with the game, and the rules and the strategy, 
not the players and their bodies, personalities, or feelings. Similarly, boys and men who are "into politics" are often imagined to be spectators, interested in strategy and policy, and are maybe even described as "policy wonks", a term Clinton used to describe herself in a keynote address at a conference of Minnesota health care professionals in 1993, although she came off as cold, rather than playfully strategic (Campbell 1998, p. 9).

Masculine passion and obsession are associated with technical mastery, data, and memorabilia collection; men have, as Henry Jenkins has been arguing for decades, been pathologised for their fan attachments and "geeky" behaviour, but the engagement and the connotations of (and therefore responses to) said engagement for male fans is drastically different from that of female fans, or fangirls. Jenkins (2013) argues that the male fan, especially the science-fiction or comic-book fan represented in The Big Bang Theory, are seen as emotionally detached from everyday life. Like the boys and men "into politics", they do not connect on a human or emotional level, but through their "fantasy worlds", whether that is Star Trek or Star Wars or foreign policy. This often translates into a perceived inability for the male fan to engage with women, or to engage in sexual or romantic activity. Jenkins states:

[E]ven though Big Bang has added female characters in recent seasons, the women remain largely outside the fannish circle: it's almost a crisis anytime a woman ventures into the comic shop; Bernadette and Amy are both female scientists, but they do not show much interest in science fiction. (p. xvi)

Not only does The Big Bang Theory-which Jenkins argues is a more nuanced representation of fans on mainstream television than he had previously seen (p. xv)-represent male fans as weird and detached from human emotion, but the TV show also represents women as outside of that world. When Penny, the main female character, is depressed about her dead-end job and gets into online gaming to cope, it is only at the suggestion of one of the fanboy characters (Sheldon), and she quickly becomes addicted, has a "lightbulb" moment when she is hit on by one of the other fanboy characters (Howard) within the online game, and snaps out of it, all within one episode ("The Barbarian Sublimation" 2008). Clearly, this is not her world, and not how she copes with sadness, loss, or lack of direction.

When women are "fans", both the objects of their fandom (often, celebrities or relationships between characters, as opposed to science-fiction world-building) and their mode of engagement are understood to be different from male fans. Female fans carry with them the connotation of being "too close" to the object of their fandom; they care too much, are too involved, and are, as fan studies scholars Katherine Larsen and Lynn Zubernis (2012, p. 1) say, "anything but detached":

Male media fans may fear that being a fanboy evokes images of the 40-year-old virgin still living in his mother's basement and collecting Star Wars light sabers. In other words, the fear is of being perceived as sexually unsuccessful [...] For female fans, the site of fan shame may be different, and perhaps more persistent in a decade when Comic Con fanboys are reclaiming the word 'geek' with revolutionary fervor. While male media fans fear being perceived as not sexual enough (the stereotypical fanboy virgin living in his mother's basement), female fans seem fearful that being a fan makes them too sexual, or at the very least too emotional. (p. 59)

Bury notes that the term fangirl "quickly became a powerful heteronormative minusmale subject position" (2005, p. 37), always the hopelessly delusional fangirl, carrying the "pejorative connotations of crazy, hysterical, and stalker" (Zubernis \& Larsen 2012, p. 228), and 
never a woman, never an objectifying or objective fan or supporter. During the 2016 U. S. election, however, this outrage emerged from within campaign coverage, drawing a gendered line between the behaviours and emotional responses of the "serious political supporter" (who is interested in facts and policy) and the "emotional fangirl" (who is interested in memes, feelings, and "girl power" above all). The "personalisation of politics" that "is often configured as a threat to 'real' issues" (Marshall \& Henderson 2016, p. 4) is even more threatening when the candidate, her supporters, and her "brand" are rooted in the figure of the "girl".

\section{“AfFective Clusters" and Twitter Followers: Political Persona, Celebrity, AND SOCIAL MEDIA}

While celebrity politicians and political celebrities are not a new thing, the requirement for a politician to have a celebrity "brand" (and for a celebrity to take a political stance, although that is another matter outside of the scope of this paper) is relatively new. In 2004, Graeme Turner wrote in Understanding Celebrity that it is "probably a commonplace observation to point out that the systems used to produce celebrity in the entertainment and sports industries are very similar to those now used to produce the public persona of the politician" and he predicted that the "rise of gossip journalism and the talk show" will continue to influence "how the process of mass mediated self-presentation must be organised" (pp. 130-1). Similarly, in a 2006 chapter on celebrity politicians focusing on Bono and Arnold Schwarzenegger, Philip Drake and Michael Higgins suggested that politicians were beginning to address their electorate as audiences, and that "[c]ontemporary politicians are aware that an appearance on a popular television show enables them to reach a wider public and circulate their image more effectively than any conventional political speech in parliament" (p. 88). Thus, just over ten years ago, celebrity studies scholars were viewing political celebrity as the cultivation of a distinctly different persona, with a different "audience" in mind, than Hollywood or "traditional" celebrity.

Reaching even further back to the 1990s, Bill Clinton's sex scandal being both political and celebrity news was a novelty. His saxophone playing on The Arsenio Hall Show (which was, of all places, late night television:' a media slot that has now become almost mandatory for politicians to retain relevancy, particularly with younger constituents) in 1992, made political history ("3 June 1992"). By June 10, 2013, however, Hillary Clinton had "taken to Twitter" (to use the terminology employed when a celebrity tweets in a noteworthy manner, usually in response to a controversy or a particular story. For example, Kim Kardashian "took to Twitter" to defend herself against critics of her nude selfies). As Karrin Vasby Anderson and Kristina Horn Sheeler point out in "Texts (and tweets) from Hillary: meta-meming and postfeminist political culture" (2014, p. 224), in her "inaugural tweet", she addressed "the short-lived but enormously popular Tumblr 'Texts from Hillary,' in which [then] Secretary of State Clinton was pictured engaging in fictional text exchanges with politicians, leaders, and celebrities". What is fascinating is that not only has the culture shifted in the last two or three decades - from seeing politicians' appearances on television shows that are not dedicated to politics or news as noteworthy, to seeing Obama's tweets going viral or Clinton responding to a Tumblr meme about herself as not just entertaining but normal-but also that Hillary Clinton was there the whole time.

Thus, while I consider her political persona as the first woman to almost become president, I want to keep in mind her status and reputation as a political celebrity, public figure, and feminist icon prior to her run for president, and how her previous persona impacts this particular narrative of "fangirling". Clinton and her supporters were often dismissed in an explicitly gendered way specifically during her 2016 presidential campaign. But this dismissal, 
and the employment of the rhetoric of fangirling that became the grounds for this dismissal, is inextricably tied to Clinton's previous political persona (as a lawyer, senator, first lady, and Secretary of State) as well as her move to seize power (rather than having it bestowed upon her by Bill Clinton-i.e. her role as first lady—or Barack Obama-i.e. her role as Secretary of Stateor the viral memes of Tumblr-i.e. her role as the sassy, taking-no-shit, badass texting Hillary) and her cultivation of a pop-culture-savvy celebrity persona in "this political climate", where a social media presence is a requirement seemingly regardless of who you are or what you do.

In 2014, Marshall published a call-to-action for "persona studies", or "the mapping of the proliferation of the public self". He argued that since the 1970s, celebrity news has become more and more normalised as part of our culture, with the biggest moment perhaps being "the migration of celebrity stories from the back-sections to the front pages of the newspapers" and the consequent collusion of gossip and news, the breakdown of celebrity and politics "via a more intense revelatory news discourse on the intimacy of political scandals and their play of public and private" (pp. 154 \& 157). Perhaps no one-outside of the royal family-experienced this collapse of public and private in political news in the same way that Bill and Hillary Clinton did with the infamous Monica Lewinsky scandal, and Hillary Clinton's involvement in said scandal - both the fact that she was implicated in a scandal at the apex of celebrity and political news, and the fact that she was both pitied and blamed as the "jilted wife" in the narrative of the scandal—cannot be ignored in an analysis of her 2016 persona.

The reasons Marshall gives for this desire for "intimacy" in both celebrity and political news offer more insight into Hillary Clinton's ongoing celebrity; he argues that the fascination and focus on celebrity demonstrates that "despite all the efforts at providing the material and information for an informed citizenry, we are drawn to emotional connections that express another force of organisation, interest and connection" (2014, pp. 153-4). That is, we want to engage emotionally. While we may scoff at the newest scandal, or laugh at former leader of the Canadian New Democratic Party Tom Mulcair doing Drake's "Hotline Bling" dance in an attempt to appeal to youths, or even dismiss those who want to keep up with the Kardashians while terrorist attacks are occurring in the world, we do care. Marshall explicitly links this contradictory response to individualised consumer capitalism and contemporary advertising's focus on selling sentiment and emotion-similar to Pepsi's attempt to sell the refreshing taste of resistance against police brutality using Kendall Jenner in 2017 ("Kendall Jenner for PEPSI Commercial").

Marshall posits that as "celebrity culture" becomes more of a "wider persona culture"meaning, as Alice Marwick and danah boyd (2011) argue, that celebrity is less of a line separating the famous from the regulars, but a continuum along which we all engage in similar practices of self-branding, or constructing a "persona" - what is at the heart of this wider persona culture is affect (2014, pp. 161-2). According to Marshall:

[Lawrence] Grossberg's (1987: 175-197) concept of an "affective economy," where emotion is attributed and in a sense rationalised, captures the way that public individuals congeal not only attention but clusters of support not dissimilar to the way that social media use attracts friends and followers for individuals. [...] Moreover, affect can move through populations as it attaches to other retained but unconscious emotional memories and thus can exhibit patterns of contagion, magnification and amplification [...] Affect allows us to understand the movement between the self and the social [... and] in combining affect theory with making sense of how social networking is reorganising 
society, one can begin to see that the various micropublics social network culture produces are in effect affect clusters. (p. 162)

In other words, people's emotional responses and attachments congeal around particular figures, celebrities, or personae, and these attachments-which Marshall likens to social media followers-can define the relationship between the self and the social, the private and the public, and can therefore create "affect clusters" or "micropublics" around particular figures and/or feelings.

There are several reasons why this argument is particularly enlightening when it comes to Clinton's persona and her so-called "fangirls", one of which Anderson and Sheeler (2014, p. 228) state succinctly: back when "she officially launched her [first] presidential campaign in January of 2007, Clinton was a known political commodity with a long public history" (emphasis added). Her "affective cluster", so to speak, already existed when she launched her Twitter account, her bio (in 2007) lauding her as a "wife, mom, lawyer, women \& kids advocate, FLOAR, FLOTUS, US Senator, SecState, author, dog owner, hair icon, pantsuit aficionado, glass ceiling cracker, TBD" (qtd in Anderson \& Sheeler, pp. 224-5). Anderson and Sheeler focus on how, in her bio and elsewhere, she tried to capitalise on that pre-existing affective narrative and congeal new emotional attachments around a pre-established figure. But, at the same time, these attempts "to define herself 'not as a staid politician but as a witty, self-effacing and almost hip netizen"' and "by [her] passions, [her] famil[y], and the chapters in [her] li[fe]", as opposed to simply her profession, were ultimately ineffective at broadening her affective cluster (Anderson \& Sheeler, p. 225). The passion, enthusiasm, and lack of rational detachment associated with her political persona and her affective cluster limit "its potential to promote effectively female presidentiality" (Anderson \& Sheeler, p. 230).

Democratic strategist and digital director of Obama's re-election campaign Teddy Goff claims that Clinton's Twitter bio "suggested someone more interested in building genuine relationships with her fans than in being 'on message' in the traditional, political sense of the term" (qtd in Llorente 2013). Marshall and Henderson (2016, p. 4) point out that this move is in line with contemporary political marketing strategies: there is an "increasing move to affect in politics" and "voters are drawn to politicians who resemble their values and attitudes". But as Anderson and Sheeler point out, Clinton was "a woman who once was reviled in U.S. political culture" (2014, p. 238). Karlyn Kohrs Campbell recounts in her article, "The discursive performance of femininity: hating Hillary" (1998, p. 1), that Clinton was pictured on the cover of Spy magazine in 1992 with "her head on the body of an S \& M dominatrix"; she was "given a defined and recognized role" in the White House "as a way to counter fears of the power of the first lady"; in 1996, Henry Louis Gates Jr. "wrote that 'Hillary-hating has become one of those national pastimes which unite the elite and the lumpen'”; also in 1996, Garry Willis wrote that "Hillary Hate is a large-scale psychic phenomenon [...] Talk shows are full of speculation about Hillary's purported lesbianism and drug use". Any attempts to soften or make likeable Clinton's political persona must not only take Clinton's femininity into account, but they must also occur within the context of this "Hillary-hating" that has become integral to Clinton's persona.

As of May 2017, Clinton has removed "glass ceiling cracker" from her Twitter bio, but she has left her political credentials as well as "hair icon" and "pantsuit aficionado"-clear cracks at her celebrity persona, rather than her politics (@HillaryClinton 2017). However, this persona, and the jokes about her hair and her clothing, is inextricably tied to Clinton's decadesold, persisting image as a tough, authoritative, ball-busting, masculine and/or emasculating woman succeeding in a place she does not really belong (Campbell, for instance, describes how she is both inappropriately feminine and masculine: she rhetorically performs masculine 
expertise, as opposed to feminine intuition, as a woman in "male spaces", e.g. the courtroom, the White House, and thus unsettles everyone (1998)). The political persona she is attempting to capitalise on in her Twitter bio is the same political persona that has kept her from breaking the glass ceiling, as opposed to just cracking it.

By cheerfully gaining the upper hand with a "cool" Twitter bio, and through "imagined exchanges with politicians, leaders, and celebrities" in the "Texts from Hillary" memes (Smith and Lambe 2012), Clinton generates a strong affective response amongst her supporters, primarily women, who have stood by her, respected her, defended her, and idolised her all along. However, this affective response, while celebrating "women's power", does little to address "the misogyny that constrains women in politics" and "derid[es] women who fail to achieve the successes modeled by [...] tokens of success" (Anderson \& Sheeler 2014, p. 233). In other words, the power of Clinton's persona is a postfeminist power; it celebrates the (potential) success of one "glass-ceiling cracker" while failing to address the underlying misogyny-the equation of presidentiality with masculinity - that stops women from destroying said ceiling altogether.

Despite her failure to turn "cool" into "presidential", Clinton is more than just the first woman to almost become president of the United States, and the impact of her persona reaches far beyond her political office. She is and has been a feminist icon for many women for decades, and has been a consistently present figure in the lives of many women (and men) who voted in the 2016 U.S. election, or watched (nervously) from afar. Personally speaking, I recall bonding with my own mother over the media's unfair treatment of Clinton during her husband's presidency and the fallout of the Lewinsky scandal. Clinton is referred to as the hero for nerdy, driven girls growing up in the 1990s and early 2000s in television series such as Gilmore Girlsan entire episode revolves around the protagonist, Rory Gilmore, worrying she will not get into Harvard because her "Hillary Clinton essay will be just like every other girl's Hillary Clinton essay because apparently that's all we can think of" ("Application Anxiety" 2003)—while young female celebrities such as Lena Dunham, Amy Schumer, Katy Perry, Ilana Glazer, Abbi Jacobson, and more tout her as their badass, political, pantsuit-wearing hero. For these women, Hillary Clinton is Madeleine Albright meets Princess Diana meets Madonna meets Meryl Streep. There is a power (and a longevity) to her persona as a distinctly female celebrity that transcends her simply being a politician.

In "this political climate", governmental politics, celebrity, social media and reality television are overlapping in unprecedented ways, and "serious" political campaigning is intersecting with fannish pleasure and outrage in an historic moment for women in American politics. Potential voters are viewed simultaneously as potential "fans", and the discourse of fangirling is used both to dismiss women's affective responses to political candidates (female political candidates in particular) and to create affective communities, or clusters, that cohere around women's responses to their Queen Hillary-a political celebrity and trailblazer in her own right for decades - almost becoming the first female president of the United States of America.

\section{The Cultural Value of (FAN)Girls: Political Persona, Fans, and Femininity}

While politicians having a celebrity persona and fan base is not "new", the use of the specific rhetoric of fangirling, and the incorporation of fangirl desire and enthusiasm into the politician's celebrity persona, is a more recent phenomenon, as pop culture fandom and the practices of fangirling in particular have entered the public sphere and the mainstream media. Fangirling has become more visible as the "bedroom culture" of "teenybopper" celebrity worship that 
Angela McRobbie (1991, p. 11) discusses in her earlier work-creating collages of New Kids on the Block from Tiger Beat, pretending to make out with a poster of Donny Osmond, watching 90210 while gushing about the newest plot developments on a three-way call during commercial breaks-has become part of the public sphere of online social media, so much so that the language of fangirling has entered into dominant discourse (e.g. using the word "squee!" to respond to something that gives one "the feels", or makes one feel overwhelming emotion). The private sphere is now being enacted in public; the bedroom is both in the privacy of the home and on the public platforms Twitter and Tumblr. Consequently, these once private expressions of emotion are witnessed by the general public, and by the objects of the fangirls' fandom, thus shifting cultural perceptions of fans, girls, and the object of fandom: and these "objects", or cultural texts or celebrity personae, shift to respond to these newly public displays of adoration and support.

Clinton did not invent the concept of a politician having "fans", but the persona that was cultivated for herii throughout her 2016 presidential campaign (which is distinct, although not wholly separate, from her previous political persona) was unique in three ways. First, this discourse of fangirling had already become public and mainstream, so was easily leveraged by politicians, journalists, and other commentators in response to her vocal, passionate, and largely female fan/supporter base. Second, while politicians have arguably always been "celebrities", the cultivation of a social-media-based celebrity persona for politicians has only become mandatory within the last decade, as discussed in the previous section, and thus Clinton is part of the "new class" of politicians required to use the tools and practices of persona and image management used not only by "regular" or Hollywood celebrities, but by everyone else as well (Kim Kardashian-West has a Twitter account; as does Barack Obama; as does Hillary Clinton; as do I; as does my retired, decidedly non-famous father).

Third, Hillary Clinton is a woman. Both former U.S. President Barack Obama and current Canadian Prime Minister Justin Trudeau have "fangirls" - they are relatively young (for politicians), attractive, photogenic, amicable, and clearly successful, so of course the girls would fall for their smiles. But there are some key differences between Obama, Trudeau, and Clinton. Obama's and Trudeau's fangirls are understood to base their fandom on sexual or romantic attraction (the stereotypical fangirl previously discussed). Clinton's fangirls, alternatively, are running on a message of solidarity and "girl power", which is inherently more threatening to the status quo.

For example, during Obama's 2008 presidential campaign, a "fangirl" became a celebrity in and of herself: the "Obamagirl". In June 2007, she, along with a four-person team, released the "Crush on Obama" video, which Bustle claims struck "comedic, political, and somewhat sexual gold" (Chang 2014). Obama and his campaign team never embraced nor endorsed the video, likely due to its raunchy innuendos, which could detract from the potential presidentiality of a relatively young, black, and not socially conservative man. However, this articulation of America, and American women in particular, having a "crush" on Obama, as the "Obamagirl" Amber Lee Ettinger said, "encompassed what a lot of Americans were feeling, the excitement for hope and change" (Hannity 2012). In some ways, this video may not take the "Obamagirl" or Obama entirely seriously, and may reflect poorly on his presidentiality, as it has been defined by his white male predecessors. But, as Ettinger points out, "Crush on Obama" responds to an already heightened level of excitement, optimism, and hope around the 2008 election that transcended gendered lines, and the Obamagirl's specific enthusiasm falls in line with the expectations I outlined above, in that she expressed heterosexual desire for Obama. While she may not be taken seriously-the comedic nature of her song, plus the fact that she was hired to do this and never personally endorsed Obama, aligns her more with late-night sketch comedy 
than Tumblr fangirling - this is the kind of fangirling we are comfortable with, as opposed to the aforementioned unabashed "girl power" enthusiasm for Clinton and a potential first female president.

While Obama and Trudeau may face criticism for their youth, celebrity affiliations, and lack of seriousness, the unabashed girlishness of the fangirls' behaviour does not reflect on them in the same way is does on Clinton. Regardless of the girls, the men's work is their work, and their personae retain (for the most part) the gravity associated with political office. Because of the girls, and because of Clinton's unprecedented femininity as a presidential candidate, Clinton becomes increasingly associated with the frivolity of pop culture and the leisure sphere, and her political persona loses weight (and not in the way that Trump has suggested many women should lose weight).

It is worthwhile to return to Jenson's aforementioned frustrations with the divide between "serious" academic pursuits and "deviant" or frivolous fan attachments. Jenson takes issue with the academy's seemingly arbitrary lines between what authors/artists or texts/works qualify as appropriate academic "work" (in her case, James Joyce) and what is "fun" or decidedly "not work" (again, in her case, Barry Manilow). This divide is reflected in how, even if the Joyce scholar admits to "enjoying" Joyce or being a "fan", Joyce has been culturally positioned as labour and Manilow as leisure. This is not completely arbitrary, nor is it not understandable, but the point is that cultural understandings of what differentiates labour from leisure depends on an infantilisation and feminisation of particular modes of engagement with cultural texts and objects that is inextricably tied to the economic and cultural valuation of the bodies engaging and the texts/objects with which they are engaging.

This narrative of fangirling (as opposed to just being a fan) is mobilised differently in regard to Clinton than it is for Obama or Trudeau, because the object of the fangirl affection (i.e. Clinton) is inherently feminised. The cultural valuation of this enthusiasm emerges not solely from the fangirls, but from the reciprocal relationship between the fangirls and the object and/or celebrity of their affection. Thus, Clinton being a woman, and being the first female Democratic presidential nominee, is crucial to understanding the impact of Clinton's fangirls, and her engagement with her fangirls, on her political and celebrity persona. The incorporation of the rhetoric and practices of "fangirling" into Clinton's presidential candidate persona is both explicitly gendered and tied to her particular celebrity persona, which has been part of the North American political and public consciousness since the early 1990s, and her social media and pop culture "literacy" or fluency, which concretises her always already feminised image in the sphere of leisure and emotional attachment, as opposed to labour and rational thought.

A defining characteristic of both girls and youth in Western culture is a lack of "work", of participation in paid labour (with this definition often used to dismiss girls' labour as "just for fun" rather than compensable). Thus, it follows that, for youth, leisure affiliations become the way identities are negotiated, communicated, and maintained. This is similar to how Dick Hebdige's (1979) punks and mods identified themselves and their socio-political and racial positioning through fashion and stylistic choice, musical tastes and affiliations, and their regular hangout spots (the street, the club). Hebdige was integral in shifting the way that cultural studies scholars write about youth. Rather than approaching youth as a "problem to be solved", he took the styles and objects of youth (sub)cultures seriously, interrogating the "processes whereby [these] objects are made to mean and mean again as 'style' in [these] subculture[s]" $(1979$, p. 3). He imbued these youth cultures, and the specific cultural objects they take up and use for their own purposes and pleasure, with value - not monetary value, but social, cultural, and political value. 
However, Hebdige's work does not do the same to value girls' youth cultures as it does boys'. Not all leisure, and not all work, is created equal, or valued equally, within patriarchal capitalism, and the value of said leisure and labour is not inherent. Instead it is constantly being created and recreated through those who engage in, witness, and critique these forms of leisure and labour. In Where the girls are: growing up female with the mass media, Susan J. Douglas (1994, p. 5) writes of baby-boomer girls:

According to the prevailing cultural history of our times, the impact of the boys was serious, lasting, and authentic. They were the thoughtful, dedicated rebels, the counter-culture leaders, the ones who made history. The impact of the girls was fleeting, superficial, trivial [...] Histories of the sixties still focus on the boys, their music and their politics, while [the girls] appear as nothing more than mindless, hysterical, out-of-control bimbos who shrieked and fainted while watching the Beatles or jiggled our bare breasts at Woodstock. Idiots, hysterics, dumbos-empty vessels.

In other words, the stories we tell about the (gendered) past become our gendered past. The boys of the sixties counterculture have cultural value because they have been imbued with cultural value by scholars such as Hebdige, who proposed viewing the boys as politically and culturally meaningful rather as a "problem", and other members of the "parent culture" (e.g. parents, teachers, politicians, journalists, other authority figures). Anderson and Sheeler argue that

the panoply of digital discourses that comprise political culture does not substitute for political reality it becomes political reality. Political identity is, therefore, less a reflection of a politician's authentic self and more a conflation of diverse and sometimes conflicting image fragments. (2014, p. 228)

Just as the stories of the countercultural boys of the sixties become the prevailing narrative of the 1960s, these affective clusters of enthusiastic girls and women become Hillary Clinton's political persona.

While this "girl power" sentiment functions as a rallying cry, and while it clusters support based on affect similarly to the way Obama clustered support around the affective economy of "hope" and "change", it could not succeed in the same way as Obama's messaging did because of how girls' and women's emotional responses are seen as overriding or precluding rational, logical, or critical thought. This performative intimacy that Marwick and boyd argue is required on interactive social media platforms such as Twitter works to both create an affect cluster around, and undermine, Clinton's presidential persona, because she is a woman, as are most of her fans. However, this is rendered invisible through the very same narratives of postfeminist empowerment Clinton leveraged in the launch of her Twitter account and her presidential campaign. Anderson and Sheeler describe the narrative thusly:

[W]omen can and do capably run for president. They have the potential to be as popular with the U.S. electorate as male candidates. Any failure of their candidacies should properly be ascribed to their personal shortcomings or strategic miscalculations rather than to the continued influence of sexism in U.S. culture. (2014, p. 2)

In other words, Clinton's failure to "congeal" enough support to secure her the presidency is her failure, and her campaign's; it is completely divorced from the sexism seemingly inextricably woven through U.S. politics that equates the presidency with masculine authority. 
But the naming of Clinton's supporters-from Lena Dunham, to Huma Abedin, to some of my colleagues and friends-as "fangirls", made explicit the implicit gendering of the presidential candidates' supporters (not just the candidates themselves) throughout the campaign. Fangirls are different from fans. The term "fangirl" works to contain "feminine" expressions of fandom or adoration within a particular nonthreatening ideological space; the passion of the hysterical fangirl, shrieking and physically and emotionally out of control at the sight of her hero, can be tolerated because it is just a teenybopper phase. The "Obamagirl" can be tolerated because her desire is expected, and does not threaten the political status quo. This ideological incorporation of the overly passionate girl is how Barbara Ehrenriech, Elizabeth Hess, and Gloria Jacobs (1992, p. 526) argue parents and journalists "dealt" with Beatlemania: convince yourselves it is "as inevitable as acne and gum-chewing, and [that] adults [will] just have to weather it out". This firmly associates this behaviour with not only femininity but with youthfulness. Thus, while Clinton's pop culture affiliations and fluency, and the fangirl passion directed her way, may construct a "cool" persona, and may "congeal" followers and fans around her, the association of pop culture with the feminine and the infantile ultimately conveys a lack of seriousness on behalf of both her and her supporters.

Hebdige argues that male youth subcultures should be taken seriously, not just as a "problem to be solved", but because they have the "ability to symptomatize a whole cluster of contemporary problems" (1979, p. 87). Despite decades of work by feminist cultural studies scholars such as Angela McRobbie and Ehrenreich, Hess, and Jacobs, we, as a culture, like to deny girls this ability; we like to deny that girls' fannish pleasure and intense culture attachments might mean something beyond "girl power!" and may carry weight that does not need to be left behind in the "teenybopper" stage of life. This is why it is particularly interesting that this rhetoric of "fangirling" was employed in a presidential election: what would it mean to take "girlish" emotional responses seriously, particularly when they have tumbled out of the "bedroom culture" of "teenybopper" worship and into the very public sphere of electoral politics? Along these same lines, if "persona", as Marshall and Henderson argue, is always already political in its strategic negotiation of the individual in the social, "a fabricated reconstruction of the individual that is used to play a role that both helps the individual navigate their presence and interactions with others and helps the collective to position the role of the individual in the social" (2016, p. 1), then how is Clinton's persona reconstructed as her role as an individual becomes more publicly positioned within this explicitly and loudly "girly" social?

\section{“YAS QUEEN”: The Female Political PERSONA AND HillaRY’s FANGiRLS}

Despite Donald Trump's history of reality TV and non-political celebrity, Hillary Clinton's supporters were called "fangirls" and accused of celebrity-worship, of solely getting their news from "pop" media like BuzzFeed - where foreign policy coverage is found alongside discussions of how "dead" we are from a Clinton eye-roll-and of allowing fandom to cloud political judgment. What is interesting is how this "fangirling" was not used as merely a descriptor for her "regular", "non-famous" supporters who were screaming at her as if she were a "teenybopper" celebrity like Harry Styles. She did have a fair number of these regular, nonfamous supporters, many not even of voting age. A popular image, and one of the first that comes up (in November 2017) in a Google Image search for "Hillary Clinton fangirls", is that of a young blonde girl meeting Clinton and ecstatically looking back over her shoulder with the classic open-mouthed "OMIGOD Mom/Dad/best friend, I'm meeting Madonna/the Spice Girls/Britney Spears/Selena Gomez!" fangirl face. It is not just her reaction that is notable here, but also the fact that she literally is a girl. She could not actually vote for Clinton in the election, yet she is "fangirling" nonetheless. 
Beyond this, however, the rhetoric of "fangirling" was also used to discuss the affection, respect, and worship Clinton's peers and colleagues had for her. The term "fangirl" was not always used pejoratively. Sometimes it was, but often women-including First Minister of Scotland, Nicola Sturgeon, and Huma Abedin, the vice-chair of Clinton's 2016 campaign-selfidentified as "Hillary fangirls". Abedin recalls being a 21-year-old intern meeting the then-first lady and says she "had such a fangirl moment" and was "hooked" (Tacopino 2016); Sturgeon, on the other hand, spoke of her excitement prior to meeting Clinton at a recent New York event, stating, "I've got to be careful I don't act like a fangirl" (AOL 2017).

While the term "fangirl" is not always used in the same way, it is always an acknowledgement of excess-whether it is presented as a straight-up criticism or an apology, it suggests that the enthusiasm one feels for Clinton is too much, and too much in a particularly feminine way. It is an excuse to dismiss the over-the-top reactions as celebrity worship or gender solidarity. Both Sturgeon and Abedin wore their Clinton fangirl labels as both a point of pride and shame (i.e. "I respect this woman so much, but unabashed enthusiasm is so unprofessional").

Jessica Tarlov (2017), writing for Fox News online, began her article on Trump's first 100 days by stating: "I'm a Hillary Clinton fangirl and I feel no shame", as if shame were the default. She continues: "Does that mean I don't see her faults? Of course not", again, as if a fangirl cannot also be a critic. Nora Kelly (2016) opened an article in The Atlantic: "They were a bunch of Hillary Clinton fangirls, the women who filed into the Women's National Democratic Club here last week to volunteer for the Democratic nominee". Kelly characterises them as "all in service to a candidate they feel duty-bound to defend: not only a woman who could be the nation's first to serve as president, but a candidate who looks, thinks, lives, and talks like them". This narrative of fangirling works to dismiss women's support of Hillary Clinton in two interrelated ways. First, women's support and enthusiasm is reduced to gender solidarity. As Anderson and Sheeler state, "[w]hen support for \#TeamHillary is reduced to gender solidarity, her constituency and policy platform can more easily be dismissed even as it is cited as proof of broad cultural support for women presidential candidates" (2014, p. 238). It appears, on the surface, to be positive thing, but it also works to reduce the candidate and her supporters to solely their gender. Second, their political work is the result of fangirl attachment rather than logical reasoning and support of policy, and these women are infantilised. This is a presidential election, not a Twilight premiere; these are women working for a political cause, not girls and women engaging in fantasy escape (and although I am suggesting this should be discussed differently, I am not suggesting that we do not also take the girls and women at the Twilight premiere seriously, merely that we acknowledge these as different kinds of emotional attachment, even if they are expressed in similar manners through similar bodies).

To conclude, I want to briefly look at Clinton's appearance on the episode "2016" of Broad City, a Comedy Central series about two twenty-something female friends in New York City "fucking around", as Anne Helen Petersen puts it (2017, p. 54). In March 2016, in the middle of her campaign, Clinton appeared on an episode of the sitcom when Ilana, one of the two protagonists, works for her campaign. Both Ilana and her friend Abbi are ecstatic to meet Hillary, but need to be instructed on etiquette; for starters, screaming "yas, yas, yas" is deemed inappropriate. However, what is more interesting than Abbi and Ilana's fangirling and lack of professionalism generally-which is completely in character for them-is the response to the episode.

Was "2016" a fangirl endorsement, and, if so (or if people read it as such), how is such an endorsement folded into Clinton's political persona? Many people read the unbridled 
enthusiasm for Clinton as an unbridled endorsement by the shows stars, writers, and creators, the real-life Ilana Glazer and Abbi Jacobson, who argued in interviews that they were not trying to make a political statement. In fact, they had written the episode a year prior, when the impact may have not been the same. Jacobson states, however, that "Hillary, even regardless of where we stand-and we love Hillary-is such an iconic figure. These girls being around her is not an everyday thing. That's how we felt being around her. It was like, 'Oh, this is a different world'” (qtd in Rosen 2016). Glazer and Jacobson reserve the right to critique, or not endorse, Clinton, but what Jacobson says here relates back to Marshall's "affect clusters": Clinton's power as a political and public figure, as well as her status as the almost first female president, was aweinspiring, was deserving of unbridled enthusiasm and passion. This fangirl attachment, this pleasure at seeing this woman you've grown up admiring run for president of the United States, is powerful, but it is used to preclude critique and rational thought, and deny that girls' and women's emotional attachments and responses might "symptomatize a whole cluster of contemporary problems" (Hebdige 1979, p. 87). Political endorsement and fangirl attachment are conflated in Clinton's political persona; the presidential candidate cannot be separated from the pop culture feminist hero and her fangirls.

The episode is called "2016" because it focuses on all the things that the United States should have achieved by the year 2016: an efficient Department of Motor Vehicles, to begin with, but also a female president of the United States. This fangirling, then-and the subsequent mourning of Clinton's loss-is not solely a result of the "Buzzfeedification" of political news, but of an often lifelong desire to see this badass woman beat the odds in the biggest boys' club in the world. Anderson and Sheeler close their paper with a chillingly accurate prediction that I will repeat here: "In the context of postfeminist political culture, winning the Internet proves to be an easier task than winning the U.S. presidency" (2014, p. 239).

\section{END NOTES}

i I refer to her by her full name here, "Hillary Rodham Clinton", because the inclusion of the "Rodham" is a significant part of her cultivation of her persona as a female married politician and lawyer. However, throughout this paper, I also refer to her as "Clinton"-both to adhere to writing conventions, which privilege the "official" surname at the expense of the "first" surname, often the spot reserved for the mother's surname, and to adhere to how she was referred to, and how she referred to herself, throughout the campaign: as Hillary Clinton (Madame President if you're nasty).

ii I use this passive sentence construction to note that, although Clinton was an active party in constructing her persona, it is never clear who is "behind" a celebrity's image, and, furthermore, the persona is not a top-down construction: her supporters, fans, fangirls, and critics all contribute to the creation of said persona.

\section{WORKS CITED}

'3 June 1992', The Arsenio Hall Show, television program, CBS, USA.

'2016', Broad City 2016, television program, Comedy Central, March 16.

Anderson, KV \& Sheeler, KH 2014, 'Texts (and tweets) from Hillary: meta-meming and

postfeminist political culture', Presidential Studies Quarterly, vol. 44, no. 2, pp. 224-243. 
'Application Anxiety', Gilmore Girls, television program, The CW, October 8, Netflix, retrieved 3 November 2017.

AOL 2017, 'Fangirl' Nicola Sturgeon meets Hillary Clinton at New York women's event', AOL UK News, 7 April, retrieved 1 May 2017, <http://www.aol.co.uk/news/2017/04/07/fangirlnicola-sturgeon-meets-hillary-clinton-at-new-york-wome/>.

'The Barbarian Sublimation', The Big Bang Theory 2008, television program, CBS.

Bury, R 2005, Cyberspaces of their own: female fandoms online, Peter Lang, New York.

Campbell, KK 1998, 'The discursive performance of femininity: hating Hillary', Rhetoric and Public Affairs, vol. 1, no. 1, pp. 1-19.

Chang, L 2014, 'Does Amber Lee Ettinger, a.k.a. the 'Crush On Obama' girl, still have a thing for the president?', Bustle, 24 June, retrieved 24 November 2017,

$<$ https://www.bustle.com/articles/32774-does-amber-lee-ettinger-aka-the-crush-onobama-girl-still-have-a-thing-for-the $>$.

Crush on Obama 2007, YouTube, The Key of Awesome, 13 June, retrieved 24 November 2017, $<$ https://www.youtube.com/watch?v=wKsoXHYICqU $>$.

Douglas, SJ 1994, Where the girls are: growing up female with the mass media, Three Rivers Press, New York.

Drake, P \& Higgins, M 2006, “I'm a celebrity, get me into politics': The political celebrity and the celebrity politician', in S Holmes \& S Redmond (eds), Framing celebrity: new directions in celebrity studies, Routledge, New York, pp. 87-100.

Ehrenreich, B, Hess, E \& Jacobs, G 1992, 'Beatlemania: a sexually defiant consumer subculture?', in K Gelder \& S Thorton (eds), The subcultures reader, Routledge, New York, pp. 523-536.

Hebdige, D 1979, Subculture: the meaning of style, Routledge, New York.

@HillaryClinton, 'Wife, mom, grandma...', Hillary Clinton, Twitter, retrieved 3 November 2017, $<$ https://twitter.com/HillaryClinton>.

Jenkins, J \& Scott, S 2013, 'Textual Poachers, twenty years later', Textual Poachers: television fans and participatory culture, twentieth anniversary edition, Routledge, New York, pp. vii-l.

Jenson, J 1992, 'Fandom as pathology: the consequences of characterization', in LA Lewis (ed.), The adoring audience: fan culture and popular media, Routledge, New York, pp. 9-29.

Kelly, N 2016, 'The Hillary Clinton disciples getting out the vote', The Atlantic, 7 November, retrieved 1 May 2017, $<$ https://www.theatlantic.com/politics/archive/2016/11/hillary-clinton-women-getout-the-vote $/ 506579 />$.

Kendall Jenner for PEPSI Commercial 2017, YouTube, Kendall and Kylie, 4 April, retrieved 3 November 2017, <https://www.youtube.com/watch?v=dA5Yq1DLSmQ>.

Llorente, E 2013, 'Hillary Clinton's debut on Twitter cranks up speculation about 2016', Fox News, 12 June, retrieved 3 November 2017, $<$ http://www.foxnews.com/politics/2013/06/12/hillary-clinton-debut-on-twittercranks-up-speculation-about-2016.html>.

Marshall, PD 2014, 'Persona Studies: mapping the proliferation of the public self', Journalism, vol. 15, no. 2, pp. 153-170.

Marshall, PD \& Henderson, N 2016, 'Political Persona 2016-an introduction', Persona Studies, vol. 2, no. 2, pp. 1-18.

Marwick, A \& boyd, d 2011, 'To see and be seen: celebrity practice on Twitter', Convergence: The International Journal of Research into New Media Technologies, vol. 17, no. 2, pp. 139158.

McRobbie, A 1991, Feminism and youth culture: from Jackie to Just Seventeen, Unwin Hyman, Boston.

Petersen, AH 2017, 'Too gross: Abbi Jacobson and Ilana Glazer', Too fat, too slutty, too loud: the rise and reign of the unruly woman, Plume, New York, pp. 51-72.

Rosen, C 2016, 'Broad City: Hillary Clinton cameo not a political statement', Entertainment Weekly, 12 March, retrieved 1 May 2017, <http://ew.com/article/2016/03/12/hillaryclinton-broad-city-episode-wednesday/>. 
Smith, A \& Lambe, S 2012, 'Texts from Hillary', Tumblr, April 4-11, retrieved 1 May 2017, $<$ http://textsfromhillaryclinton.tumblr.com/>.

Tacopino, J 2016, 'Huma Abedin gushes about how she became a Hillary 'fangirl", New York Post, 5 April, 1 May 2017, <http://nypost.com/2016/04/05/huma-abedin-gushes-abouthow-she-became-a-hillary-fangirl/>.

Tarlov, J 2017, 'Trump's first 100 days, Hillary Clinton and America's missed opportunity', Fox News Opinion, 21 April, retrieve 1 May 2017, <http://www.foxnews.com/opinion/2017/04/21/trumps-first-100-days-hillaryclinton-and-americas-missed-opportunity.html>.

Turner, G 2004, Understanding celebrity, Sage Publications, London, UK.

Zubernis, L \& Larsen, K 2012, Fandom at the crossroads: celebration, shame and fan/producer relationships, Cambridge Scholars Publishing, Newcastle-upon-Tyne, UK. 